\title{
FORECASTING THE DEVELOPMENT OF CULTURAL ENTERPRISES IN THE BALTIC STATES AND UKRAINE
}

\author{
Oleksandr Darovanets ${ }^{1}$, Kateryna Darovanets ${ }^{2}$
}

\begin{abstract}
The purpose of the paper is to forecast the development of cultural enterprises in the Baltic states and Ukraine. The article identifies the practical aspect. The enterprises of the cultural sector of Lithuania, Latvia, Estonia, and Ukraine are analyzed. The development of cultural enterprises of these countries is presented graphically. The forecast is made. The trend line shows the geometric representation of the average values of the analyzed indicators obtained using any mathematical function. The displayed value of the approximation's reliability shows the compliance's degree of the trend model with the original data, as a forecast of cultural enterprises. Methodology. The following research methods were used: the method of generalization of theoretical knowledge was used to form the authors' approach to the definition of terms; tabular method, analysis, which was used to estimate the number and average size of enterprises in the field of culture in the Baltic states and Ukraine; the graphic method was used for the number of cultural enterprises in Lithuania, Latvia, Estonia, and Ukraine; the exponential method was used when constructing a trend line; the approximation method was used for the prediction equation; extrapolation method was used to calculate the projected number and the average size of enterprises in the cultural sectors in Lithuania, Latvia, Estonia, and Ukraine. Results. The forecast is based on the number of cultural enterprises per capita in the Baltic states and Ukraine. Conclusions are made and proposals for improving the activities of the cultural sector in the leading countries of the world are presented. The study is based on a review of the literature, scientific articles on the development of cultural enterprises in the Baltic states and Ukraine. Practical implications. Forecasting the development of cultural enterprises will make it possible to predict activities and avoid miscalculations in the area of the Baltic states and Ukraine. Value/originality. The results of this study provide an opportunity to further make a rating assessment for 2021 and a projected rating assessment of cultural enterprises in the Baltic states and Ukraine. This will provide an opportunity to learn about the level of development of Ukraine in comparison with leading European countries.
\end{abstract}

Key words: forecasting, development, cultural enterprises, Ukraine, the Baltic states, sectors.

JEL Classification: O11, L82, N20

\section{Introduction}

The development of cultural enterprises is a system of organization and management of cultural and artistic institutions, improvement of the legal framework. The economic crisis has worsened the activities of cultural enterprises.

During the pandemic period, there is an opportunity to rethink possible miscalculations in the cultural sector of the Baltic states and Ukraine. There are many positive moments during this period that people do not notice. One of them is the development of cultural enterprises in each country.

Corresponding author:

${ }^{1}$ Kyiv National University of Culture and Art, Ukraine.

ORCID: https://orcid.org/0000-0002-7465-5216

ResearcherID: https://publons.com/researcher/4446883//

${ }^{2}$ Kyiv National University of Culture and Art, Ukraine.

ORCID: https://orcid.org/0000-0002-3262-9247

ResearcherID: https://publons.com/researcher/4452806//
The human resources of cultural enterprises are significantly affected by the lack of timely adaptation to changes in the external environment under the influence of time and the lack of adaptation to changes in the needs of employees, mismatch of conditions and wages

There are many talented cultural workers who have traveled to different countries around the world.

This contributes to changes in the process of personnel management of cultural enterprises in the leading countries of the world. The crisis has affected the development of cultural enterprises. It has covered almost all public life and has become an important task that needs to be solved soon. 


\section{Literature review}

Antonio Vaamonde Liste and Maria do Rosário Cabrita say that the risk of the disappearance of lowlevel companies' profitability in cultural firms is slightly higher than in non-cultural ones. The behavior of cultural and non-cultural firms differ greatly in debt: show firms with high and low debt a significant difference in the risk of their disappearance, although this parameter has no statistical significance in non-cultural companies (Antonio Vaamonde Liste).

Krupka A.Ya, Pyrih H.I. believe that it is necessary to promote the material well-being of the population. This will increase the consumption of cultural services. Positive effects of strong culture exceed the eventual negative effects of such culture and positively influence the level of enterprises' dynamics (Krupka, Pyrih, 2017; The importance of culture for enterprise dynamics...).

Kyrychuk $O$. includes among the factors that positively influence the increase of efficiency of investment processes in the sector of culture: the interest of the state and society in the development of culture; diversity of the main activities of cultural institutions, development of creative industries; improving the quality and diversity of cultural services. In European countries, public funding of culture is also carried out based on intergovernmental transfers by transferring local and targeted transfers to local budgets. In Norway, municipalities receive from the government a block grant to finance health, education, and culture. Some municipalities are allocated a block grant to finance libraries; funds are distributed between local budgets in proportion to the population. Another promising form of subsidizing the cultural sphere is partnership participation of the state and corporate sponsors, which contributes to a significant inflow of funds from the private sector. Joint projects, for example, in the UK are funded by central budget and sponsorship funds in a ratio of $1: 1$ for the first project and 1:3 for subsequent projects. In France, a larger share of state participation is envisaged - the budget contribution and the sponsor's funds are 5:1, money is allocated subject to the prior collection of a certain amount of sponsorship funds (Kyrychuk, Maksymyak, 2008).

\section{Analysis number and the average size of enterprises in the cultural sectors in the Baltic states and Ukraine}

Let us see into the analysis. Number and the average size of enterprises in the cultural sectors in Western Europe (Table 1).

According to Table 1, we can see that in the years 20132018 number and the average size of enterprises in the cultural sectors' the Baltic states and Ukraine changed. In Latvia, the number of enterprises increased by 1431 or $38.06 \%$. This indicator in Lithuania in 2018 compared to 2013 increased by 5688 , that is $82.77 \%$. It is seen that in Estonia this indicator from 2013 to 2018 was positive, simply increased by 1061 cultural enterprises, that is increased by $38.92 \%$. In Ukraine cultural enterprises from 2013 to 2018 was decreased by 87 , that is increased by $10.53 \%$. We can see that Lithuania had the largest number of cultural enterprises and Ukraine had the smallest number of cultural enterprises from 2013 to 2018.

Let us see into dynamics. Number and the average size of enterprises in the cultural sectors in Lithuania (Figure 1).

According to Figure 1, it is seen that number and the average size of enterprises in the cultural sectors in Latvia in 2013 as compared with 2018 had an upward trend. Let us see the dynamics. The trend line is a geometric representation of the average values of the analyzed indicators, obtained using any mathematical function. $\mathrm{R} 2$ is the value of the approximation's reliability shows the degree of the trend model's compliance with the original data. Its value is 0.949 , which is close to 1 . The value of $\mathrm{R} 2$ shows that the model describes the data with high accuracy.

Using the trend extrapolation method, we calculated that the predicted number and average size of enterprises in the cultural sectors in Lithuania will be: in 2021 increased by 6305 cultural enterprises; in 2022 increased by 17100 cultural enterprises; in 2023 increased by 18160 cultural enterprises.

Let us see into dynamics. Number and the average size of enterprises in the cultural sectors in Latvia (Figure 2).

Table 1

Number and the average size of enterprises in the cultural sectors in the Baltic states and Ukraine

\begin{tabular}{|c|c|c|c|c|c|}
\hline Year & Latvia & Lithuania & Estonia & Ukraine & Total size in Europe \\
\hline 2013 & 3759 & 6872 & 2726 & 826 & 1161698 \\
\hline 2014 & 3913 & 9019 & 2885 & 729 & 1195166 \\
\hline 2015 & 4609 & 10195 & 3138 & 750 & 1185689 \\
\hline 2016 & 5074 & 10957 & 3261 & 764 & 1231553 \\
\hline 2017 & 5007 & 11653 & 3605 & 763 & 1244269 \\
\hline 2018 & 5190 & 12560 & 3787 & 739 & 1285203 \\
\hline Change in 2018 compared to 2013 & 1431 & 5688 & 1061 & -87 & 123505 \\
\hline \% Change in 2018 compared to 2013 & +38.06 & +82.77 & +38.92 & -10.53 & -5.21 \\
\hline
\end{tabular}

Source: compiled by the authors based on Eurostat (State of Eurostat) 


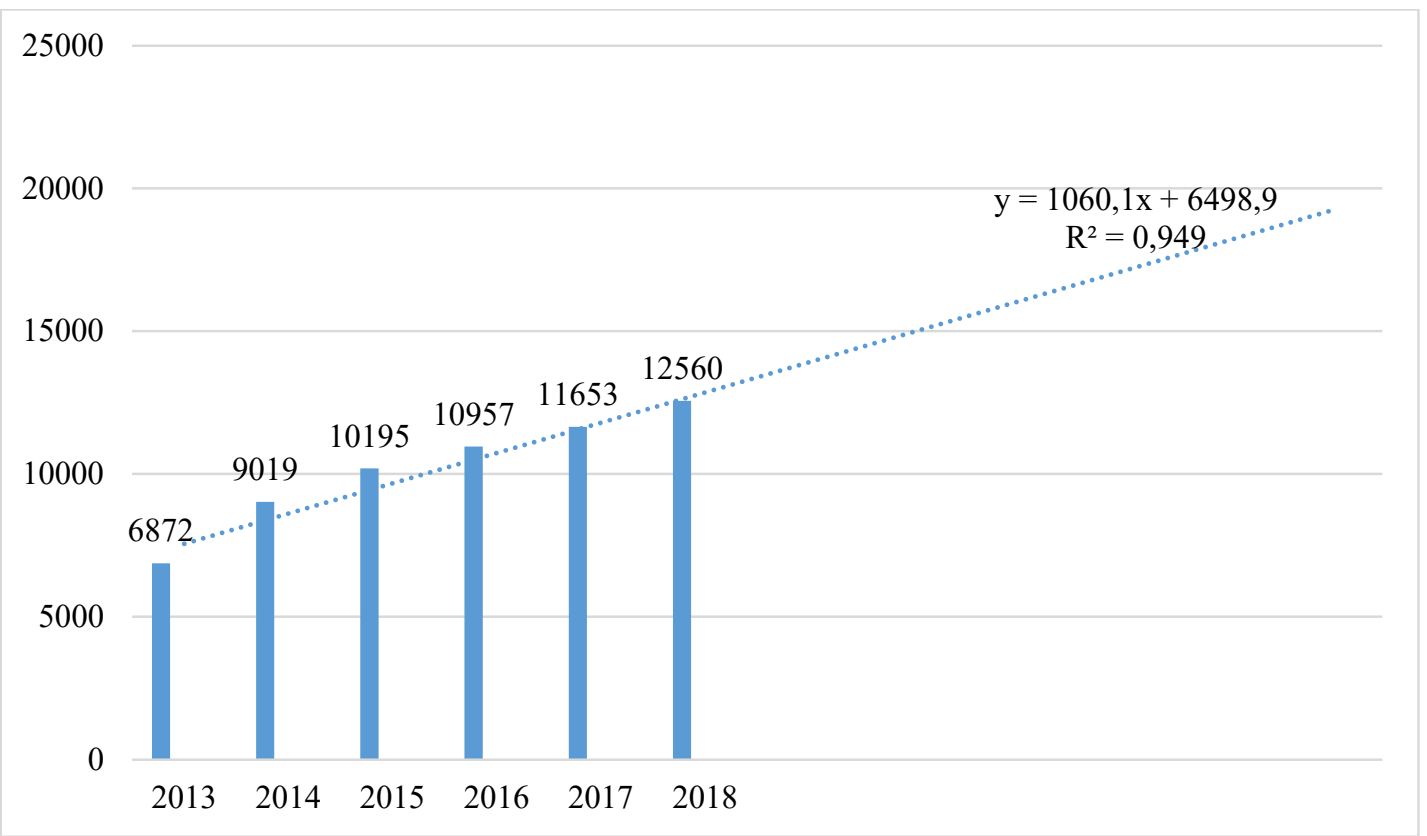

Figure 1. Number and the average size of enterprises in the cultural sectors in Lithuania

Source: compiled by the authors based on Eurostat (State of Eurostat)

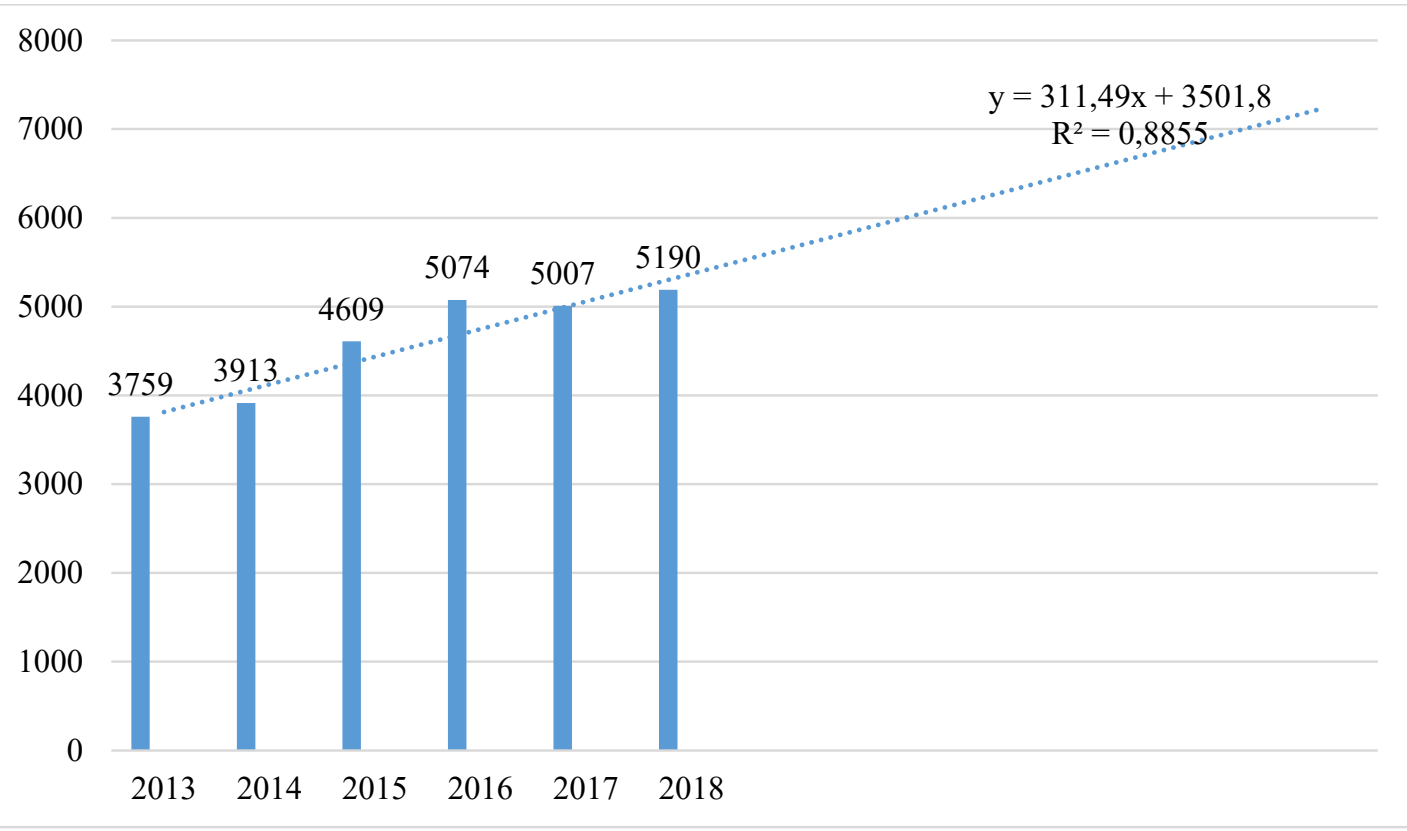

Figure 2. Number and the average size of enterprises in the cultural sectors in Latvia

Source: compiled by the authors based on Eurostat (State of Eurostat)

According to Figure 2, it is seen that number and the average size of enterprises in the cultural sectors in Latvia in 2013 as compared with 2018 had an upward trend. Only in 2017, we can see a decrease in this indicator. The trend line is a geometric representation of the average values of the analyzed indicators, obtained using any mathematical function. $\mathrm{R} 2$ is the value of the approximation's reliability shows the degree of the trend model's compliance with the original data. Its value is 0.8855 , which is close to 1 . The value of $\mathrm{R} 2$ shows that the model describes the data with high accuracy.

Using the trend extrapolation method, we calculated that the predicted number and average size of enterprises in the cultural sectors in Latvia will be: in 2021 increased by 6305 cultural enterprises; in 2022 increased by 6617 cultural enterprises; in 2023 increased by 6928 cultural enterprises. 
Let us see into dynamics. Number and the average size of enterprises in the cultural sectors in Estonia (Figure 3).

According to Figure 3, it is seen that number and the average size of enterprises in the cultural sectors in Estonia in 2013 as compared with 2018 had an upward trend. The trend line is a geometric representation of the average values of the analyzed indicators, obtained using any mathematical function. Its value is 0,9871 , which is close to 1 . The value of $\mathrm{R} 2$ shows that the model describes the data with high accuracy.
Using the trend extrapolation method, we calculated that the predicted number and average size of enterprises in the cultural sectors in Estonia will be: in 2021 increased by 4426 cultural enterprises; in 2022 increased by 4643 cultural enterprises; in 2023 increased by 4860 cultural enterprises.

Let us see into dynamics. Number and the average size of enterprises in the cultural sectors in Ukraine (Figure 4).

According to Figure 4, it is seen that number and the average size of enterprises in the cultural sectors

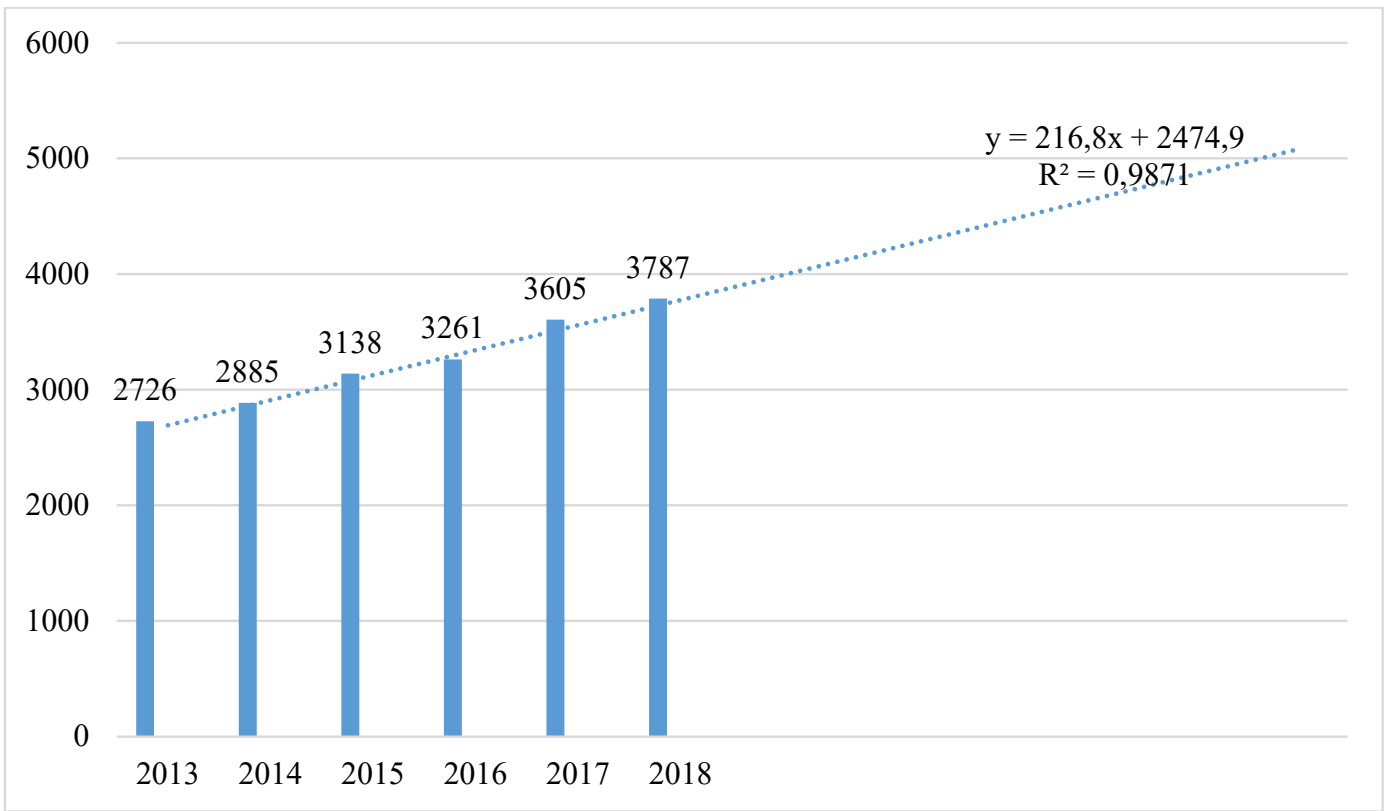

Figure 3. Number and the average size of enterprises in the cultural sectors in Estonia

Source: compiled by the authors based on Eurostat (State of Eurostat)

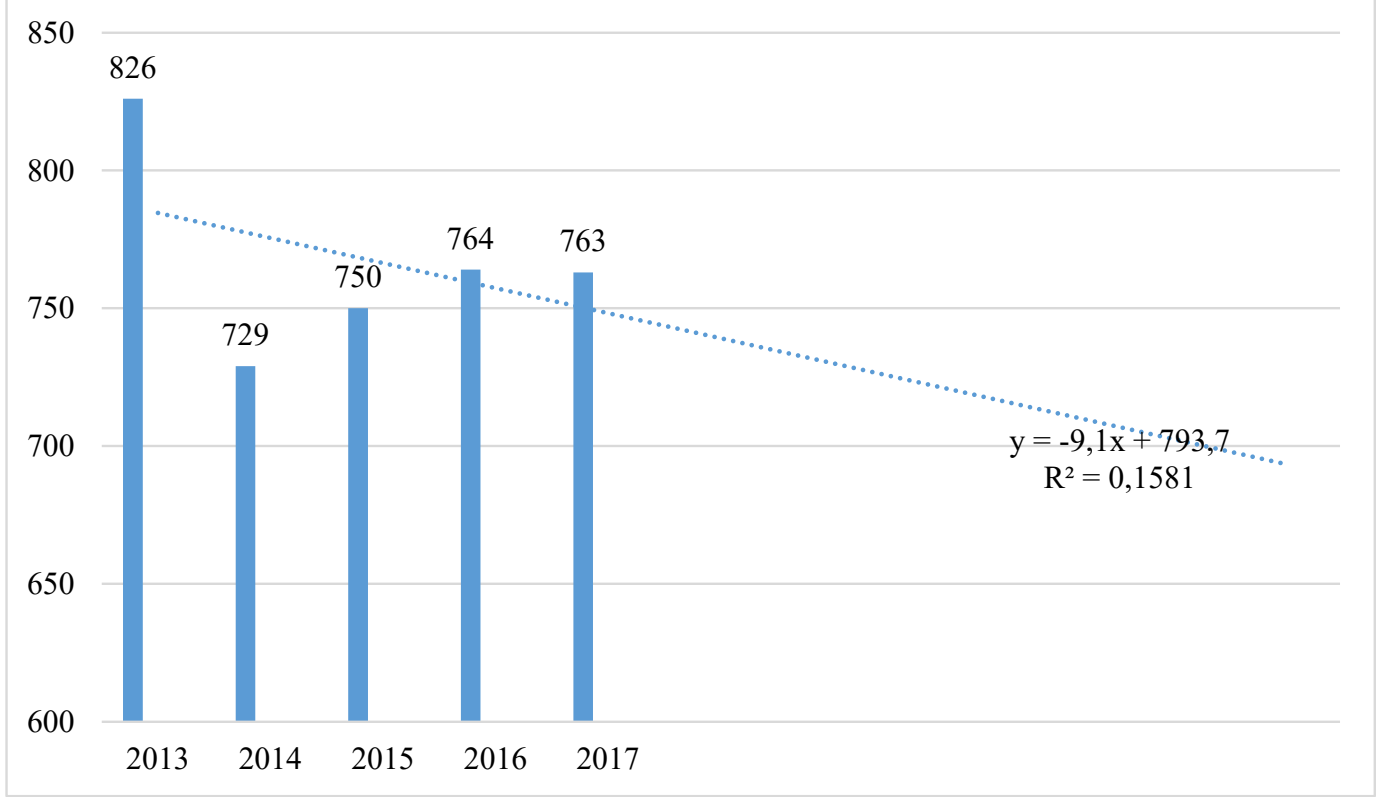

Figure 4. Number and the average size of enterprises in the cultural sectors in Ukraine

Source: compiled by the authors based on the State Statistics Service of Ukraine (State Statistics Service of Ukraine) 
in Ukraine in 2013 as compared with 2018 tended to down, especially in 2014. The trend line is a geometric representation of the average values of the analyzed indicators, obtained using any mathematical function. $\mathrm{R} 2$ is the value of the approximation's reliability shows the degree of the trend model's compliance with the original data. Its value is 0.1581 , which is close to 1 . The value of $\mathrm{R} 2$ shows that the model describes the data with high accuracy.

Using the trend extrapolation method, we calculated that the predicted number and average size of enterprises in the cultural sectors in Ukraine will be: in 2021 increased by 712 cultural enterprises; in 2022 increased by 703 cultural enterprises; in 2023 increased by 694 cultural enterprises.

Let us see into dynamics. Number and the average size of enterprises in the cultural sectors in the Baltic states and Ukraine (Figure 5).

According to Figure 5, we can see that Lithuania had the largest number of cultural enterprises among the countries of the Baltic states and Ukraine. The smallest number of cultural enterprises in Ukraine from 2013 to 2018 .

\section{Number of cultural enterprises per 1 person in The Baltic states and Ukraine}

Let us see into the analysis. The number of cultural enterprises per 1 person in the Baltic states and Ukraine (Table 2).

According to Table 2, it is seen that number of cultural enterprises per 1 person the largest in 2021 in Latvia, which is $0.86 \%$, and the smallest in Ukraine, which is $0.01 \%$ among the studied countries. This indicator for January 1, 2021: Lithuania 0.24\%; Estonia 0.34\%.

Let us see into forecast indicators analysis. The number of cultural enterprises per 1 person in the Baltic states and Ukraine (Table 3).

According to Table 3, it is seen that is forecasting number of cultural enterprises per 1 person the largest in 2025 in Latvia, which is $1.12 \%$, and the smallest in Ukraine, which is $0.01 \%$ among the studied countries.

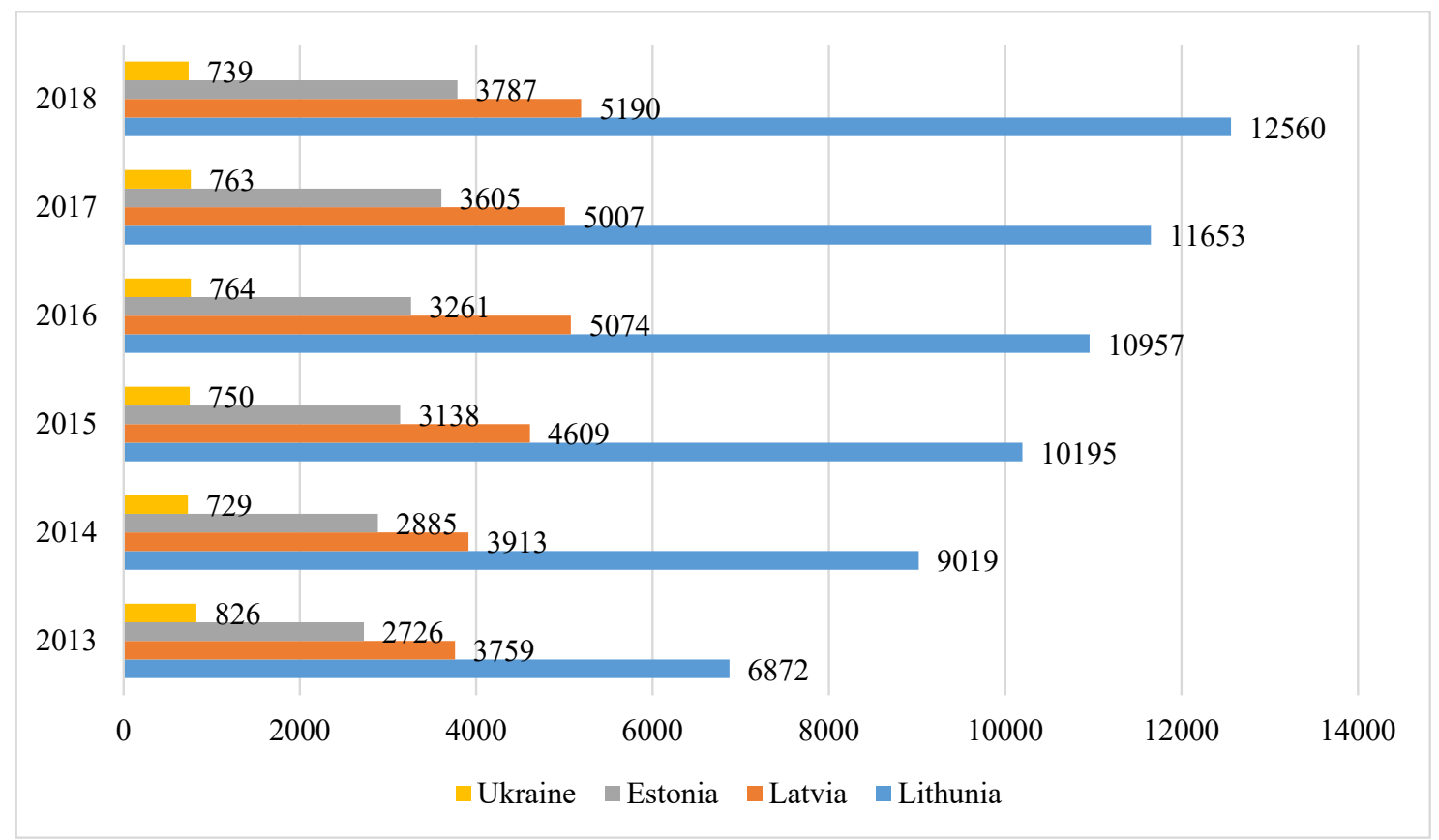

Figure 5. Number and the average size of enterprises in the cultural sectors in the Baltic states and Ukraine, 2013-2018

Source: compiled by the authors based on Eurostat and the State Statistics Service of Ukraine (State of Eurostat; State Statistics Service of Ukraine)

Table 2

Number of cultural enterprises per 1 person in the Baltic states and Ukraine, January 1, 2021

\begin{tabular}{|l|c|c|c|c|}
\hline \multicolumn{1}{|c|}{ Country } & Lithuania & Latvia & Estonia & Ukraine \\
\hline Population & 2680976 & 1866316 & 1320831 & 41588400 \\
\hline Number of cultural enterprises & 6305 & 16040 & 4426 & 712 \\
\hline number of cultural enterprises per 1 person, \% & 0.24 & 0.86 & 0.34 & 0.01 \\
\hline
\end{tabular}

Source: compiled by the authors based on the State Statistics Service of Ukraine and Eurostat (State of Eurostat; State Statistics Service of Ukraine; The population of Lithuania; The population of Latvia; The population of Estonia; State of Minfin of Ukraine) 
Table 3

Forecasting number of cultural enterprises per 1 person in the Baltic states and Ukraine, January 1, 2025

\begin{tabular}{|l|c|c|c|c|}
\hline \multicolumn{1}{|c|}{ Country } & Lithuania & Latvia & Estonia & Ukraine \\
\hline Population & 2788017 & 1812685 & 1280130 & 41466200 \\
\hline Number of cultural enterprises & 7551 & 20280 & 5293 & 675 \\
\hline number of cultural enterprises per 1 person, \% & 0.27 & 1.12 & 0.41 & 0.01 \\
\hline
\end{tabular}

Source: compiled by the authors based on the State Statistics Service of Ukraine and Eurostat (State of Eurostat; State Statistics Service of Ukraine; The population of Lithuania; The population of Latvia; The population of Estonia; State of Minfin of Ukraine)

\section{Conclusions}

Summarizing the results of the development of cultural enterprises in the Baltic states and Ukraine, we can draw the following conclusions:

- Lithuania had the largest number of cultural enterprises among the countries of the Baltic states and Ukraine. The smallest number of cultural enterprises in Ukraine from 2013 to 2018;

- using the trend extrapolation method, we calculated that the predicted number and average size of enterprises in the cultural sectors in Lithuania will be: in 2021 increased by 6305 cultural enterprises; in 2022 increased by 17100 cultural enterprises; in 2023 increased by 18160 cultural enterprises;

- the predicted number and average size of enterprises in the cultural sectors in Latvia will be: in 2021 increased by 6305 cultural enterprises; in 2022 increased by 6617 cultural enterprises; in 2023 increased by 6928 cultural enterprises;

- this indicator in Estonia will be: in 2021 increased by 4426 cultural enterprises; in 2022 increased by 4643 cultural enterprises; in 2023 increased by 4860 cultural enterprises;

- the predicted number and average size of enterprises in the cultural sectors in Ukraine will be: in 2021 increased by 712 cultural enterprises; in 2022 increased by 703 cultural enterprises; in 2023 increased by 694 cultural enterprises;

- the number of cultural enterprises per 1 person is the largest in 2025 in Latvia, which is $0.86 \%$, and the smallest in Ukraine, which is $0.01 \%$ among the studied countries. This indicator for January 1, 2021: Lithuania $0.24 \%$; Estonia 0.34\%;

- forecasting number of cultural enterprises per 1 person the largest in 2025 in Latvia, which is $1.12 \%$, and the smallest in Ukraine, which is $0.01 \%$ among the studied countries.

We will provide recommendations for the improvement of cultural enterprises in the Baltic states and Ukraine, that is:

- to develop a mechanism for managing the quality of services, the functioning of cultural enterprises;

- increase the relationship between cultural enterprises and consumers of cultural services through advertising, incentives;

- cultural workers need to cooperate with workers of different countries in the cultural sector;

- to establish the relationship between cultural enterprises and universities in terms of cultural literacy; - it is necessary to give creative teams more independence in choosing the direction of their development, the formation of repertoire policy, the organization of both main and commercial activities.

\section{References:}

Antonio Vaamonde Liste, Maria do Rosário Cabrita. The Survival of Cultural Firms: A Study of Multiple Accounting Parameters in Spain. DOI: https://doi.org/10.3390/su12031159

Krupka, A. Ia., \& Pyrih, H. I. (2017). Industry and culture as an important component of the country's economic system. Bulletin of Odessa National University named after I. Mechnikov, 11 (64), 189-192.

The importance of culture for enterprise dynamics: the role of type and strength of culture. Available at: https://www.tandfonline.com/doi/full/10.1080/1331677X.2016.1168038 (accessed 06 May 2021).

Kyrychuk, O., \& Maksymyak, L. (2008). Improving the mechanisms of financing cultural and artistic activities in Ukraine. Efficiency of public administration, 14/15, 277-285.

State of Eurostat. Available at: https://ec.europa.eu/eurostat/databrowser/view/cult_ent_num/default/ table?lang=en (accessed 29 April 2021).

State Statistics Service of Ukraine. Available at: http://ukrstat.gov.ua/imf/arhiv/nr/nr2016_2020_u.htm Accessed 05 April 2021 (accessed 30 April 2021).

The population of Lithuania. Available at: https://countrymeters.info/ru/Lithuania (accessed 19 April 2021).

The population of Latvia. Available at: https://countrymeters.info/ru/Latvia (accessed 20 April 2021).

The population of Estonia. Available at: https://countrymeters.info/ru/Estonia (accessed 19 April 2021).

State of Minfin of Ukraine. Available at: https://index.minfin.com.ua/reference/people/ (accessed 19 April 2021). 